\title{
INVESTIGATIONS ON THE ROLE OF WILD RODENTS AS RESERVOIRS OF HUMAN SCHISTOSOMIASIS IN THE TAVETA AREA OF KENYA, EAST AFRICA ${ }^{1}$
}

\author{
Kenjiro Kawashima ${ }^{2}$, Daisuke Katamine ${ }^{3}$, Makoto Sakamoto ${ }^{3}$, \\ Masaaki Shimada ${ }^{3}$, Hisatake Nojima ${ }^{4}$ \\ AND Michiaki Miyahara ${ }^{2}$ \\ Received for publication 1 August 1978
}

\begin{abstract}
These investigations were carried out in some of the villages around Taveta Town, Coast Province, Kenya, during the dry seasons of 1974, 1975 and 1976. The authors examined 83 wild rodents from villages where there is a high infection rate of $S$. mansoni and/or $S$. haematobium. The number and species of the rodents collected were as follows: 41 Pelomys sp., 2 Arvicanthis sp., 6 Dendromus sp., 5 Thamnomys sp., 1 Rattus rattus from Jipe, 4 Pelomys sp., 3 Arvicanthis sp., 3 Mastomys sp. from Eldoro, 1 Pelomys sp., 10 Arvicanthis sp., 7 Mastomys sp. from Kivalwa. Among them, 18 Pelomys sp. (43.9\%) from Jipe and 1 Pelomys sp. $(25.0 \%)$ from Eldoro proved to be infected with Schistosoma flukes. These flukes were identified as $S$. mansoni on the basis of their morphological features as well as the infectivity to their transmitters. In the experimental exposure of Biomphalaria sudanica to miracidia obtained from Pelomys sp., a number of cercariae were observed. This snail also proved to be infected with $S$. mansoni from human infection. From these investigations, it was suggested that the creek rodent, Pelomys sp. may play the role as a reservoir host of Schistosoma mansoni in this area.
\end{abstract}

\section{INTRODUCTION}

For a long time it was generally believed that in Africa the transmission of Schistosoma mansoni and S. haematobium was entirely interhuman. However, in 1952 a schistosome of man was found by Kuntz in a rodent and this stimulated a great deal of laboratory and field investigations on rodents as reservoirs of human schistosomiasis in Africa.

According to the reviews by Nelson (1960) and Nelson et al. (1962), a variety of wild animals including wild rodents have been found naturally infected with $S$. mansoni or $S$. haematobium, but up to the time of the present investigation there was no

1 Studies on Schistosomiasis in Kenya, East Africa (Report 3) conducted by Schistosomiasis Research Team (Leader: D. Katamine), Institute for Tropical Medicine, Nagasaki University and Kenyan Counterparts, supported by a Scientific Research Grant from the Ministry of Education, Japan. 2 Laboratory of Medical Zoology, School of Health Sciences, Kyushu University, Fukuoka, Japan. 3 Department of Parasitology, Institute for Tropical Medicine, Nagasaki University, Nagasaki, Japan. 4 Department of Medical Zoology, Faculty of Medicine, Kagoshima University, Kagoshima, Japan. 
evidence to suggest that rodents played a part in the transmission of human schistosomiasis in Africa.

During the dry seasons of 1974, 1975 and 1976, the authors carried out field and experimental investigations on the role of wild rodents as reservoirs of human schistosomiasis in the Taveta area of the Coast Province of Kenya. The present paper reports the results of these investigations and records a high infection rate of $S$. mansoni in wild rodents.

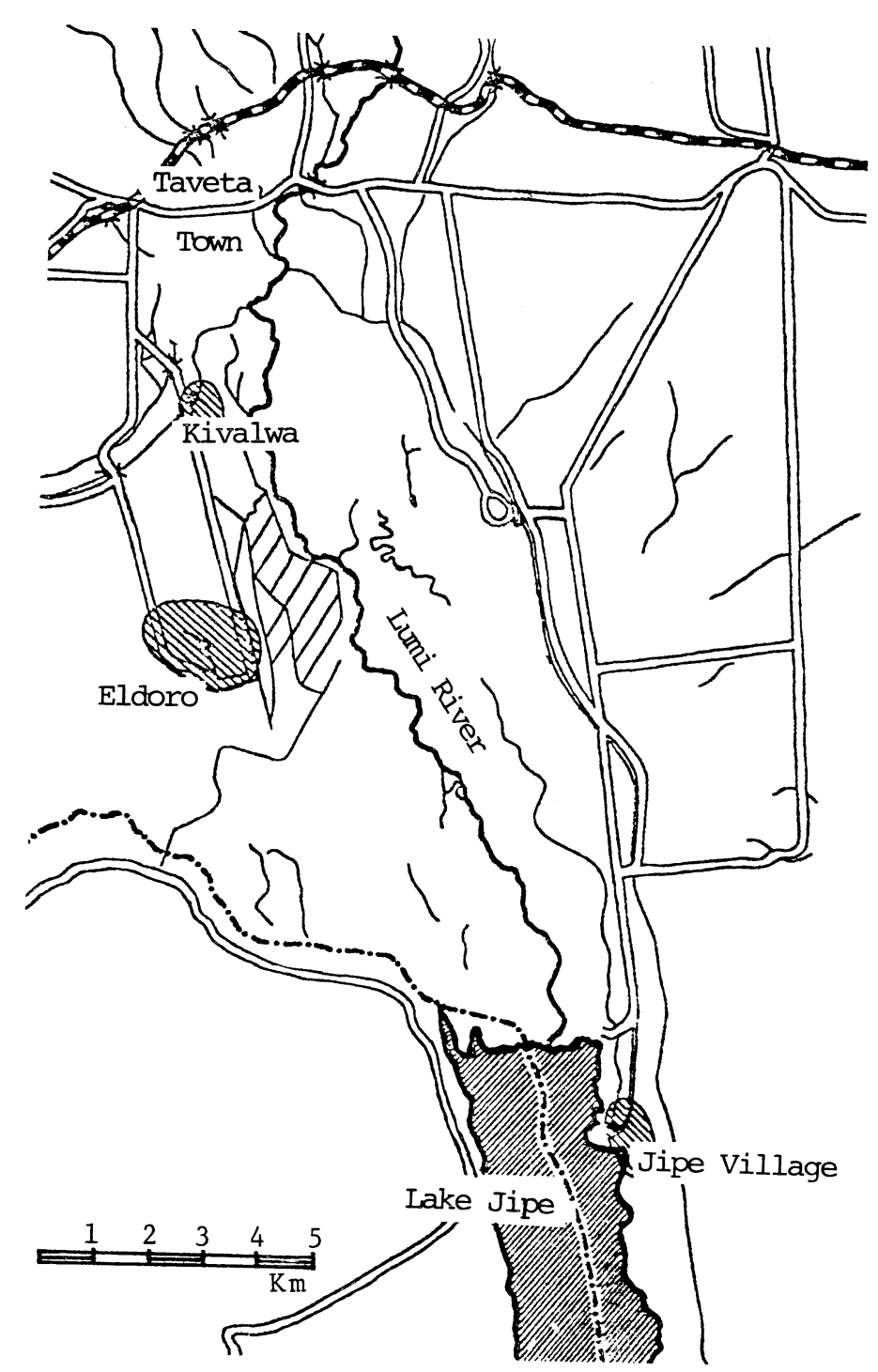

Figure 1 Map of the Taveta area, Coast Province, Kenya showing the locations of villages studied. 


\section{Materials AND Methods}

Most of the wild rodents were captured by cage traps in the papyrus swamp along the Lake Jipe shore (Figure 1). The traps were also set in the sugar cane field along the irrigation canals in the villages Kivalwa and Eldoro.

The technique used in examining the rodents in 1974 was to crush the liver and portal veins between glass plates under a dissecting microscope to search for adult schistosome flukes and to crush pieces of liver and intestine between slides and examine them with a higher objective for eggs.

In 1975, the wild rodents were anaesthetized with Nembutal and the adult schistosomes were perfused from the portal veins and livers with citrated saline. The adults obtained were washed in saline and then fixed in Bouin's solution with slight pressure under a cover slip at the room temperature. These adults were preserved in 70 per cent ethanol. After sending them to Japan, they were stained with Carmine and mounted.

In order to collect the eggs of the schistosomes, the liver and intestine of the rodent were washed with saline and homogenized. After separating the residues, they were washed several times. The residues were examined under a dissecting microscope and the eggs were collected with a Pasteur pipette. These eggs were measured and compared with those from human infections.

Miracidia were hatched from the eggs obtained from the infected rodents, and were exposed to Biomphalaria sudanica that originated from Lake Jipe.

\section{RESUlts}

(1) Natural infection of wild rodents with schistosome

The results of the field investigation are summarized in Table 1. As shown in

Table 1 Natural schistosome infections in wild rodents in the Taveta area

\begin{tabular}{|c|c|c|c|c|c|c|c|c|c|c|}
\hline \multirow{2}{*}{$\begin{array}{l}\text { Species of } \\
\text { rodent }\end{array}$} & \multirow{2}{*}{$\begin{array}{l}\text { Villages } \\
\text { surveyed }\end{array}$} & \multicolumn{3}{|c|}{1974} & \multicolumn{3}{|c|}{1975} & \multicolumn{3}{|c|}{ Total } \\
\hline & & $\begin{array}{l}\text { No. ex- } \\
\text { amined }\end{array}$ & $\begin{array}{l}\text { No. in- } \\
\text { fected }\end{array}$ & $(\%)$ & $\begin{array}{l}\text { No. ex- } \\
\text { amined }\end{array}$ & $\begin{array}{l}\text { No. in- } \\
\text { fected }\end{array}$ & $(\%)$ & $\begin{array}{l}\text { No. ex- } \\
\text { amined }\end{array}$ & $\begin{array}{l}\text { No. in- } \\
\text { fected }\end{array}$ & $(\%)$ \\
\hline \multirow[t]{3}{*}{ Pelomys sp. } & Jipe & 27 & 12 & $(44.4)$ & 14 & 6 & $(42.9)$ & 41 & 18 & $(43.9)$ \\
\hline & Kivalwa & & & & 1 & 0 & $(0)$ & 1 & 0 & $(0)$ \\
\hline & Eldoro & & & & 4 & 1 & $(25.0)$ & 4 & 1 & $(25.5)$ \\
\hline \multirow[t]{3}{*}{ Arvicanthis sp. } & Jipe & 2 & 0 & $(0)$ & & & & 2 & 0 & $(0)$ \\
\hline & Kivalwa & & & & 10 & 0 & $(0)$ & 10 & 0 & $(0)$ \\
\hline & Eldoro & & & & 3 & 0 & $(0)$ & 3 & 0 & (0) \\
\hline \multirow[t]{2}{*}{ Mastomys sp. } & Kivalwa & & & & 7 & 0 & $(0)$ & 7 & 0 & $(0)$ \\
\hline & Eldoro & & & & 3 & 0 & $(0)$ & 3 & 0 & $(0)$ \\
\hline Dendoromus sp. & Jipe & 6 & 0 & $(0)$ & & & & 6 & 0 & $(0)$ \\
\hline Thamnomys sp. & Jipe & 3 & 0 & $(0)$ & 2 & 0 & $(0)$ & 5 & 0 & (0) \\
\hline Rattus rattus & Jipe & 1 & 0 & $(0)$ & & & & 1 & 0 & (0) \\
\hline
\end{tabular}


Table 2 Summarized data of the positive cases of naturally infected creek rodent, Pelomys sp. with schistosomes in 1975

\begin{tabular}{|c|c|c|c|c|c|}
\hline Rodent No. & Date captured & Date autopsied & $\begin{array}{l}\text { Eggs in } \\
\text { faeces }\end{array}$ & $\underset{\text { liver }}{\text { Eggs in }}$ & Adults found \\
\hline $10 *$ & Sept. 4 & Sept. 5 & - & - & $4 \hat{\jmath}$ \\
\hline $15 * *$ & Sept. 7 & Sept. 7 & - & - & $1 \hat{\jmath}$ \\
\hline $21 *$ & Sept. 14 & Sept. 14 & - & + & 4 송, 3 우 \\
\hline $28 *$ & Sept. 17 & Sept. 17 & - & + & 2 상, 2 우 \\
\hline $\mathrm{S}-3 *$ & Oct. 8 & Nov. 5 & + & + & 2 하, 2 우 \\
\hline $\mathrm{S}-6 *$ & Oct. 16 & Nov. 11 & + & + & 8 상, 2 오 \\
\hline
\end{tabular}

* captured from Jipe. ** captured from Eldoro.

Faecal examination was done at the date autopsied.

this Table, only the creek rodent, Pelomys sp. proved to be infected with schistosomes. During the two periods of observation, 18 out of $41(43.9 \%)$ Pelomys sp. collected from the Lake Jipe shore were infected with $S$. mansoni and one out of four from Eldoro. Table 2 shows the number and sex of flukes recovered in six infected Pelomys sp. in 1975. The largest number of adult flukes was 10 (8 今, 2 우) and the smallest was one $(1 \hat{\delta})$. It should be noted that the results of faecal examination of infected Pelomys sp. with schistosomes were negative for viable eggs until October and were positive after that. Other wild rodents such as Arvicanthis sp., Mastomys sp., Dendromus sp., Thamnomys sp. and the house rat, Rattus rattus were all negative for Schistosoma infection.

(2) Diagnostic features of schistosome found in Pelomys sp.

Adult flukes (Figures 2 and 3): The intestine of the male divides immediately posterior to the oesophageal gland into two intestinal crura which reunite to form a single caecum at approximately two-fifth or two-sixth of the total length of the intestine from the anterior end of the fluke. The number of testes is five to seven. In the female, the ovary lies in the anterior half of the body. Only one egg at a time is found in the uterus.

Eggs (Figure 4): The majority of eggs recovered from liver, intestine or faeces of the rodents are generally oval in shape and bear a lateral spine. The length and width of the 100 eggs averaged $143.2 \pm 12.19$ microns and $57.7 \pm 6.58$ microns, respectively. The measurements of the eggs of schistosomes found in Pelomys sp. and those of $S$. mansoni from human infections are shown in Table 3. The differences of length and width of the eggs are not statistically significant.

Finally, these flukes found in Pelomys sp. were identified as S. mansoni on the basis of the morphological features of the adults as well as those of the eggs.

(3) Experimental infections of snails and hamsters with schistosome found in Pelomys sp.

B. sudanica experimentally exposed to miracidia obtained from the eggs of $S$. mansoni parasitic in Pelomys sp. were transferred to Japan and observed. Two of the three snails which survived 56 days after exposure produced $S$. mansoni cercariae 

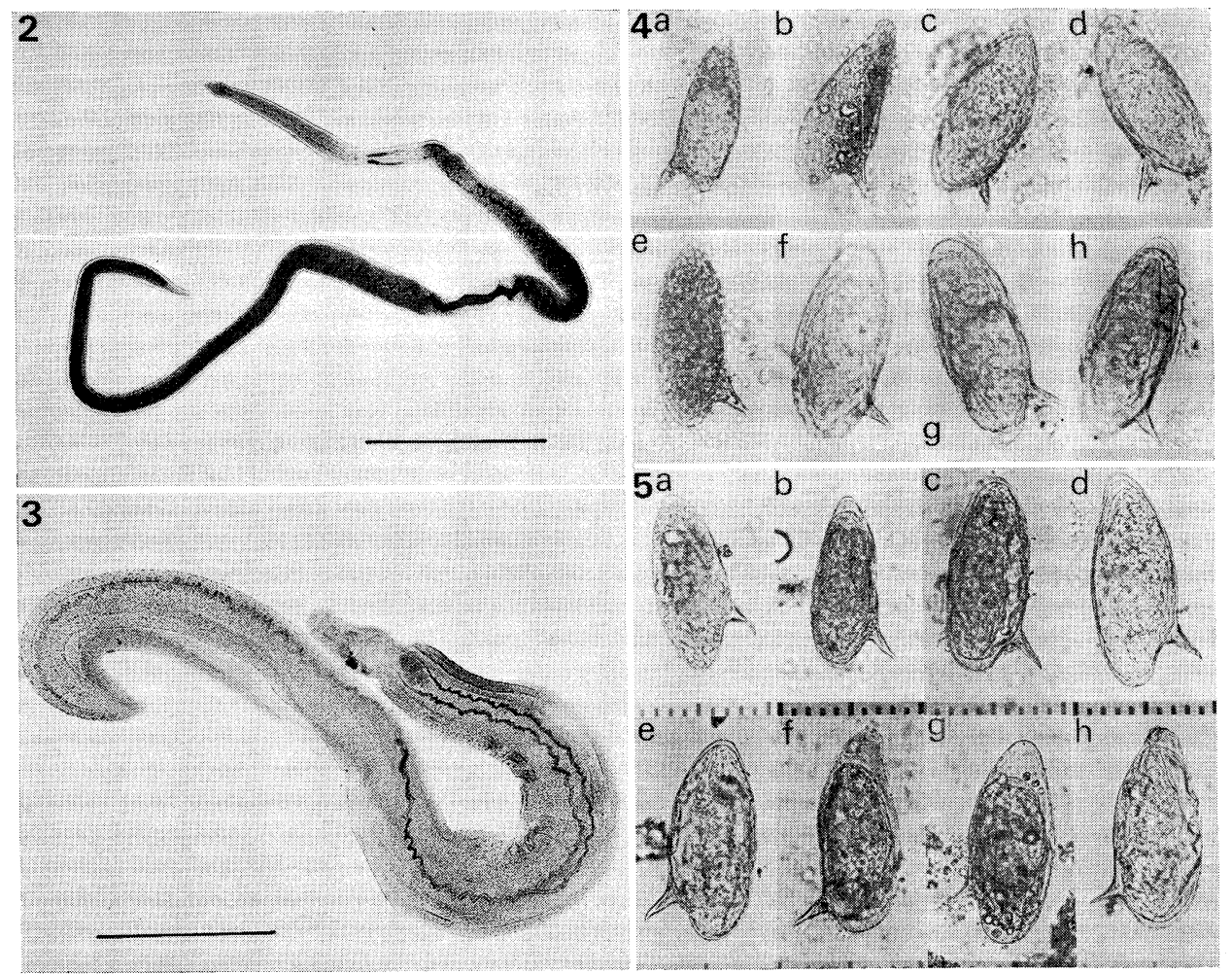

Figure 2 Adult S. mansoni (female) from wild Pelomys sp. (Scale $1.0 \mathrm{~mm}$ ).

Figure 3 Adult $S$. mansoni (male) from wild Pelomys sp. (Scale $1.0 \mathrm{~mm}$ ).

Figure 4 Eggs of $S$. mansoni from wild Pelomys sp. (Scale 10 microns).

Figure 5 Eggs of $S$. mansoni from the patient in the Taveta area (Scale 50 microns).

which were used to infect hamsters. Sixty-three days after exposure, the eggs of $S$. mansoni appeared in the faeces of the infected hamsters. The results of these experiments prove that $S$. mansoni obtained from Pelomys sp. is infective to $B$. sudanica and also to hamsters. At the same time, wild rodents were exposed to $S$. mansoni cercariae originating from human infections. In this experiment, one Pelomys sp. became infected. It was also shown that B. sudanica was susceptible to $S$. mansoni derived from human infection.

\section{Discussion}

In Africa two species and one variety of Schistosoma in the group with lateral
Table 3 Mean and standard deviation of measurements of the eggs of S. mansoni from rodent and human infections (in microns)

\begin{tabular}{lcc}
\hline & $\begin{array}{c}\text { Eggs from } \\
\text { rodents } \\
(\mathrm{n}=100)\end{array}$ & $\begin{array}{c}\text { Eggs from } \\
\text { human } \\
(\mathrm{n}=100)\end{array}$ \\
\hline Length & $143.2 \pm 12.19$ & $140.1 \pm 10.47$ \\
Width & $57.7 \pm 6.58$ & $58.3 \pm 5.45$
\end{tabular}


spined eggs have been reported: these are S. mansoni Sambon, 1907 and S. rodhaini Brumpt, 1931. S. rodhaini is common in rodents (Stijns, 1952; Schwetz, 1954), although it has never been found in human beings. According to the description of the eggs of $S$. rodhaini by Fripp (1967), the majority of eggs of $S$. rodhaini recovered from the liver, intestine or faeces of the mammalian hosts are generally oval and bear a prominent terminal or slightly subterminal spine usually directed laterally, with the angle of the direction varying from 0 to $90^{\circ}$ to the long axis of the eggs, and at the opposite end of the eggs is a short blunt tubercle which may be straight or occasionally absent, but usually bends in a direction opposite to that of the spine. Schistosomes found in the rodents in the present study are distinguished from $S$. rodhaini by the shape of the eggs which are characteristic for typical S. mansoni. Schwetz (1953) found a new schistosome in wild rodents from the Albertville area of the former Belgian Congo and named it as $S$. mansoni var. rodentorum. This fluke produces lateral spined eggs similar to those of $S$. mansoni from which it is distinguished by several features. The differences were summarized by Schwetz (1953) as follows: in general appearance the eggs are elongated and sometimes slightly twisted, with one end rounded and the other narrowed. The spine bears near - sometimes very near - to the rounded end. The notch between the base of the spine and the body of the egg is distinct and is often wide and deep. Although some of the eggs in the present study were similar to those of $S$. mansoni var. rodentorum, living miracidia were not recognized in any of them (Figures $4 a, b$ ), and the eggs of normal appearance including living miracidia were identical in shape with those typical of $S$. mansoni (Figures 4 and 5 expect $4 \mathrm{a}, 5$ ). It seems that the egg of $S$. mansoni var. rodentorum might be an abnormal form of $S$. mansoni parasitic in rodents. In fact, Schwetz (1956) has already noted that $S$. mansoni var. rodentorum might be $S$. mansoni parasitic in rodents. Teesdale and Nelson (1958) also considered that S. mansoni var. rodentorum is nothing other than $S$. mansoni in rodents. According to the study by Taylor (1970), hybridisation occurred readily between $S$. mansoni and S. rodhaini, and the hybrids produced eggs which showed clear hybrid inheritance. The eggs of schistosome in the present study were not like those of the hybrids. As shown in Table 3, there were no differences in the sizes of the eggs of $S$. mansoni between human and rodent infections. Moreover, the morphological features of the adult flukes of schistosomes found in the rodents in the present study were identical with those of $S$. mansoni originating from human infection. Finally the flukes found in the rodents in the present study were identified as $S$. mansoni based on their morphology as well as their snail hosts.

In Kenya, Nelson (1960) examined 226 rodents from the endemic areas of schistosomiasis mansoni and schistosomiasis haematobia, and found a single male schistosome of the $S$. mansoni type parasitic in only one rodent, a Dasymys. He concluded that the evidence from Africa suggested that rodents played very little part in the transmission of human schistosomiasis. According to Nelson's opinion (1960), the few positive findings were usually "dead end" infections indicating an occasional zooanthroposis with man as the maintenance host and the rodent as an incidental host. In 1962, Nelson et al. reviewed the results of further surveys of the natural infection of rodents with schistosomes in Kenya where they examined more than 
1,000 rodents. According to their study, S. mansoni was found in one out of 63 Otomys, two out of 250 Mastomys and one out of four Dasymys. S. rodhaini was found in one out of 60 Thallomys and two out of ten Lophuromys. Moreover, S. bovis was found in one Mastomys and three Lophuromys. Again, the low natural infection rate found in the rodents suggested that they were of no importance as reservoirs of human schistosomiasis in Africa. However, they concluded that since rodents can maintain $S$. rodhaini in isolated foci the examination of more swamp rodents might reveal active foci of rodent transmitted $S$. mansoni in Africa. The same authors were evidently uncertain of the role of baboons as true maintenance hosts of $S$. mansoni, even though high prevalence rates were recorded in Kenya and Uganda. Subsequent studies by Fenwick (1969) in Tanzania have shown that baboons can maintain the infection in their own community and are the source of infection to man. According to the study by Schwetz (1954) in the former Belgian Congo, schistosomiasis of rodents is chronic and seems to be of low virulence and he suggests that rodents were infected for ages before man appeared and that they came to tolerate their schistosomiasis. When man began to frequent the same watercourse and was exposed to infection, the chronic infection seen in rodents became an acute infection in the human host. This hypothesis was not supported by Pitchford and Visser (1962) who investigated the role of naturally infected wild rodents in the epidemiology of schistosomiasis in the Eastern Transvaal. Although they found schistosomiasis in rodents in a highly endemic area in their initial investigation, the original 22 per cent infection rate dropped until eventually it was extremely difficult to find any infected rodents two years later. They concluded that rodents seem incapable of maintaining $S$. mansoni infection without additional human pollution. In the present study, it is still not clear whether man contributes to the presence of $S$. mansoni in rodents or whether rodents can maintain $S$. mansoni in the absence of man, but high infection rate of $S$. mansoni among the creek rodent, Pelomys sp. and its ability to pass viable eggs in the faeces suggest that this rodent may serve as a reservoir of human schistosomiasis mansoni in this particular area. These observations suggest that further studies would be of value to determine the role of the creek rodent in the transmission of $S$. mansoni to man.

\section{ACKNowledgements}

The authors express their deep gratitude to Kenyan Government officials for their excellent cooperation to these studies. The authors are particularly grateful to Dr. J. N. Itotia, Director of the National Public Health Laboratory Services, Nairobi, Dr. T. K. A. Siongok, Head of the Division of Vector Borne Diseases, National Public Health Laboratory Services, Dr. H. K. Githaiga, Parasitologist, Division of Vector Borne Diseases and field technicians (Mr. R. L. Musa, Mr. J. Nandoya, Mr. H. Mwinga, Mr. K. Kokoi) of the Medical Research Laboratory, Division of Vector Borne Diseases, Taveta, without whose help they could not have carried out any studies in endemic areas, and to Dr. J. E. Tremlett, Director of Veterinary Services, Veterinary Research Laboratories, Kabete who kindly supplied them with hamsters.

The authors are deeply indebted to Prof. G. S. Nelson, London School of 
Hygiene and Tropical Medicine and to Dr. C. A. Wright, British Museum (Natural History), London for their helpful comments which aided in the preparation of this manuscript.

\section{REFERENCES}

1) Fenwick, A. (1969): Baboons as reservoir hosts of Schistosoma mansoni, Trans. Roy. Soc. Trop. Med. Hyg., 63, 557-567

2) Fripp, P.J. (1967): On the morphology of Schistosoma rodhaini (Trematoda, Digenea, Schistosomatidae), J. Zool., London, 151, 433-452

3) Kuntz, R. E. (1952): Natural infection of an Egyptian gerbil with Schistosoma mansoni, Proc. Helminthol. Soc. Washington, 19, 123-124

4) Nelson, G. S. (1960): Schistosome infections as zoonosis in Africa, Trans. Roy. Soc. Trop. Med. Hyg., 54, 301-324

5) Nelson, G. S., Teesdale, C. and Highton, R. B. (1962): The role of animals as reservoirs of Bilharziasis in Africa, In Chiba Foundation Symposium: Bilharziasis, 127-149, London

6) Pitchford, R. J. and Visser, P. S. (1962): The role of naturally infected wild rodents in the epidemiology of schistosomiasis in the Eastern Transvaal, Trans. Roy. Soc. Trop. Med. Hyg., $56,126-135$

7) Schwetz, J. (1953): On a new schistosome of wild rodents found in the Belgian Congo, Schistosoma mansoni var. rodentorum var. nov., Ann. Trop. Med. Parasit., 47, 183-186, 2 plates

8) Schwetz, J. (1954): On two schistosomes of wild rodents of the Belgian Congo: Schistosoma rodhaini Brumpt, 1931; and Schistosoma mansoni var. rodentorum Schwetz, 1953; and their relationship to $S$. mansoni of man, Trans. Roy. Soc. Trop. Med. Hyg., 48, 89-100

9) Schwetz, J. (1956): Role of wild rats and domestic rats (Rattus rattus) in schistosomiasis of man, Trans. Roy. Soc. Trop. Med. Hyg., 50, 275-282

10) Stijns, J. (1952): Sur les rongeurs, hotes naturels de Schistosoma rodhaini Brumpt, Ann Parasit. Hum. Comp., 27, 385, quoted by Schwetz (1954)

11) Taylor, M. G. (1970): Hybridisation experiments on five species of African schistosomes, J. Helminth., 44, 253-314, 13 plates

12) Teesdale, C. and Nelson, G. S. (1958): Recent work on schistosomes and snails in Kenya, E. Afr. Med. J., 35, 427-436 
東アフリカ・ケニア，タベタ地区における住血吸虫症の

病原保有宿主としての野生ネズミ類に関する研究 ${ }^{1}$

川島健治郎 ${ }^{2} \cdot$ 片峰 大助 ${ }^{3} \cdot$ 坂本 信 ${ }^{3}$

嶋田 雅暁 ${ }^{3}$ ・野島 尚武 ${ }^{4}$ 宮原 道明 ${ }^{2}$

この研究は，1974年，1975年および1976年の乾期（9月-12月）にケニア南部のタべタ地区に於て 行われた。マンソン住血吸虫の濃厚浸淫地である Jipe 部落の Jipe 湖畔においては Pelomys sp. 41個 体, Arvicanthis sp. 2 個体, Dendromus sp. 6 個体, Thamnomys sp. 5 個体, Rattus rattus 1 個体を 採集した。このうち, Pelomys sp. 18 個体（43.9\%）に住血吸虫の自然感染を認めた。マンソン住血 吸虫とビルハルツ住血吸虫の両種の浸淫地である Eldoro 部落では Pelomys sp. 4 個体, Arvicanthis sp. 3 個体, Mastomys sp. 3 個体を採集し, そのうち Pelomys sp. 1 個体（25.0\%）に住血吸虫の自然 感染を証明した。ビルハルッ住血吸虫の濃厚浸淫地である Kivalwa 部落では Pelomys sp. 1 個体, Arvicanthis sp. 10個体, Mastomys sp. 7 個体を採集したが，住血吸虫の感染は認められなかった。 Pelomys sp. から得られた住血吸虫の成虫につレて, 雄では腸管が食道腺の直後において 2 分し, 虫

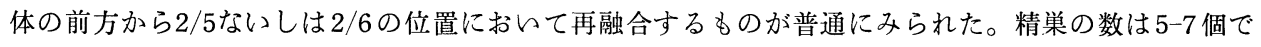
あった。雌では単純な卵巣が体の前部に位置し, 子宮内に認められる虫卵の数は 1 個であった。また, その卵の形態は卵円形を呈し，鈍角をなす卵殻端に近い側部に著しい棘を生ずる。その100個の計測 值は長径 $143.2 \pm 12.19 \mu$, 幅径 $57.7 \pm 6.58 \mu$ であった。更に捊化させて得たミラシジゥムを Jipe 湖中 に多数生息するBiomphalaria sudanica に実験的に感染させたとてろ, セルカリアまでの発育が認 められた。これらの特徵をヒトから得たマンソン住血吸虫のそれと比較したところ, 多くの点で一致 がみられた。従って Pelomys sp. から得られた住血吸虫をマンソン住血吸虫と同定した。Jipe 部落 にはマンソン住血吸虫による患者が多数みられ，乙の住血吸虫の病原保有宿主として，Pelomys 属の ネズミが，疫学上，重要な役割を演じているものと推測された。

1 ケニアにおける住血吸虫症の研究 (第 3 報) 本研究は長崎大学熱帯医学研究所に対する文部省特別 事業費により行われた。2 九州大学医療技術短期大学部医動物学研究室 3 長崎大学熱帯医学研究 所寄生虫学部門 4 鹿児島大学医学部医動物学教室 